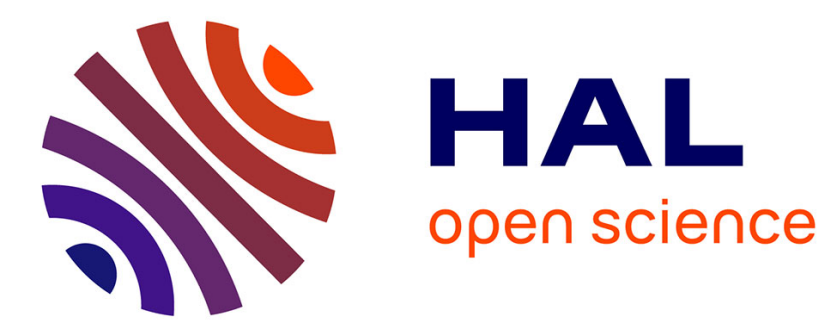

\title{
Nucleation and crystallisation in xerogel induced and probed by $\mathrm{Cr}$
}

\author{
W. Nie, G. Boulon
}

\section{To cite this version:}

W. Nie, G. Boulon. Nucleation and crystallisation in xerogel induced and probed by Cr. Journal de Physique IV Proceedings, 1992, 02 (C2), pp.C2-141-C2-144. 10.1051/.jp4:1992217 . jpa-00251288

\section{HAL Id: jpa-00251288 https://hal.science/jpa-00251288}

Submitted on 1 Jan 1992

HAL is a multi-disciplinary open access archive for the deposit and dissemination of scientific research documents, whether they are published or not. The documents may come from teaching and research institutions in France or abroad, or from public or private research centers.
L'archive ouverte pluridisciplinaire HAL, est destinée au dépôt et à la diffusion de documents scientifiques de niveau recherche, publiés ou non, émanant des établissements d'enseignement et de recherche français ou étrangers, des laboratoires publics ou privés. 


\title{
Nucleation and crystallisation in xerogel induced and probed by $\mathrm{Cr}$
}

\author{
W. NIE ${ }^{(1)}$ and G. BOULON
}

Laboratoire de Physico-Chimie des Materiaux Luminescents, Universite Lyon I, URA au CNRS $n^{\circ} 442$, Batiment 205, 69622 Villeurbanne Cedex, France

\begin{abstract}
Nucleation and crystallization from xerogels of the system $\mathrm{SiO}_{2}-\mathrm{ZnO}$ $\mathrm{Al}_{2} \mathrm{O}_{3}$ are induced and probed by $\mathrm{Cr}$. Besides the traditional techniques, such as X-ray diffraction, SAXS and TEM, ESR and optical techniques especially laser spectroscopy are employed for the investigation of the structural evolution during thermal treatments of these xerogels. $\mathrm{Cr}$ is served not only as a structure probe but also a nucleating agent. The devitrification of the system is found to be essentially initiated by the presence of traces of chromium.
\end{abstract}

\section{Introduction}

Nucleation and crystallization behaviours in glasses of the systems of $\mathrm{SiO}_{2}-\mathrm{MgO}$ $\mathrm{Al}_{2} \mathrm{O}_{3}$ and $\mathrm{SiO}_{2}-\mathrm{ZnO}-\mathrm{Al}_{2} \mathrm{O}_{3}$ doped with $\mathrm{Cr}_{2} \mathrm{O}_{3}$ have been sludied in the laboratory for many years (1,2.3). Apart from the classical techniques used for these kinds of studies, such as X-ray diffraction. SAXS, TEM, ESR and optical techniques especially laser spectroscopy are employed in the current investigation concerning sol->gel->glass->glass-ceramic transitions in the $\mathrm{SiO}_{2}-\mathrm{ZnO}-\mathrm{Al}_{2} \mathrm{O}_{3}-\mathrm{Cr}_{2} \mathrm{O}_{3}$ system. Some results have been published in three different journals(4.5.6). A parallel study was also carried out on the spectroscopic properties of $\mathrm{Cr}^{3+}$ doped gahnite $\mathrm{ZnA}{ }_{2} \mathrm{O}_{4}$ which serves as a reference to follow the nucleation and crystallization processes $(7,8)$. In contrary, the spectroscopic evolution of chromium during the nucleation and crystallization processes traces back the physical origins of the three most important $\mathrm{Cr}^{3+}$ fluorescent centres in $\mathrm{ZnAl}_{2} \mathrm{O}_{4}$ crystals $(7,8)$.

In the current paper, we would like to summarize this work from a totally different point of view. Chromium is regarded as essentially a structure probe in the previous publications(1-6). After a brief of the role of chromium to the structural evolution in the systems. some general aspects of utilizing a probe to study structural evolutions are discussed. 
The preparation of samples have been described in references 5. Apart from the relative molar ratios between $\mathrm{SiO}_{2} / \mathrm{Al}_{2} \mathrm{O}_{3} / \mathrm{ZnO}$, essential results reveal the dominant role played by traces of chromium to the structural evolution.

\section{Summary of principal results}

$X$-ray diffraction patterns shows the presence of $\mathrm{Cr}^{3+}$-doped $\mathrm{ZnAl}_{2} \mathrm{O}_{4}$ crystallites only in the samples thermally treated at high temperatures $\left(>800^{\circ} \mathrm{C}\right)$. The sol->gel- $>$ glass transitions and the first stage of nucleation process can not be evidenced by this classical technique. The final crystalline phases in different samples are gahnite, mullite, quartz and willemite depending on initial compositions(5).

TEM micrographs shows the appearance of crystallites in the samples both in the beginning of nucleation and the end of crystallisation(6). From electron diffraction micrographs, on measuring the diameters of diffraction circles calibrated by an Al reference sample, lattice constants of crystallites as a function of heating temperatures for two samples Gel8 and KCR2 are obtained(Fig. 1). This rigure clearly shows that the nucleation and crystallisation processes are initialed by $\mathrm{Cr}^{3+}$ agreggations. The initial concentration of chromium $(0.3 \mathrm{~mol} \%$ for Gele and $1 \mathrm{~mol} \%$ for K(R2) determines the number of nuclei in the beginning of nucleation(at $800^{\circ} \mathrm{C}$ ) and the final chemical composition of the crystallites at the end of crystallisation(at $\left.1000^{\circ} \mathrm{C}\right)$.

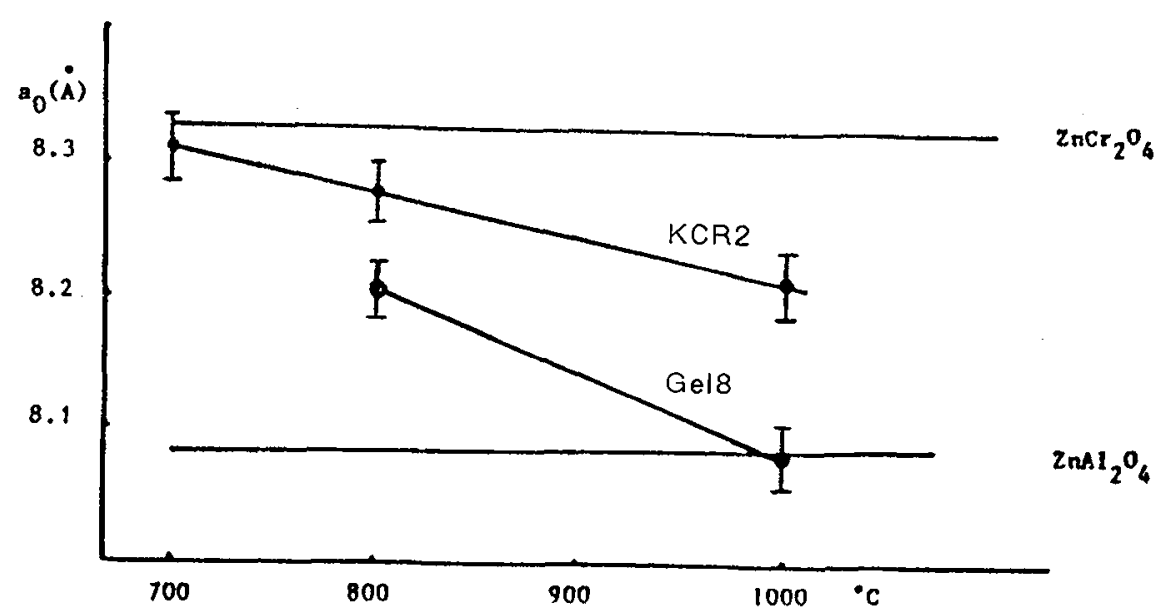

Fig. 1 Lattices constants of crystallites obtained from electron diffraction. 
Optical absorption and ESR spectra confirm the presence of $\mathrm{Cr}^{6+}$ and the formation of cluster radicals around $\mathrm{Cr}^{6+}$. The $\mathrm{Cr}^{3+}<->\mathrm{Cr}^{6+}$ oxido-reduction occurs at the gel$>$ glass transition stage till the beginning of nucleation(5). Fig. 2 shows the absorption spectra of Gel8 and $\mathrm{KCR} 2$ heat-Ireated at $1000^{\circ} \mathrm{C} . \mathrm{Cr}^{3+}$-doped $\mathrm{ZnAl}_{2} \mathrm{O}_{4}$ and $\mathrm{ZnCr}_{2} \mathrm{O}_{4}$ crystals are served as references. The different peak positions of Gel8 and KCR2 are directly related to their initial chromium concentrations.

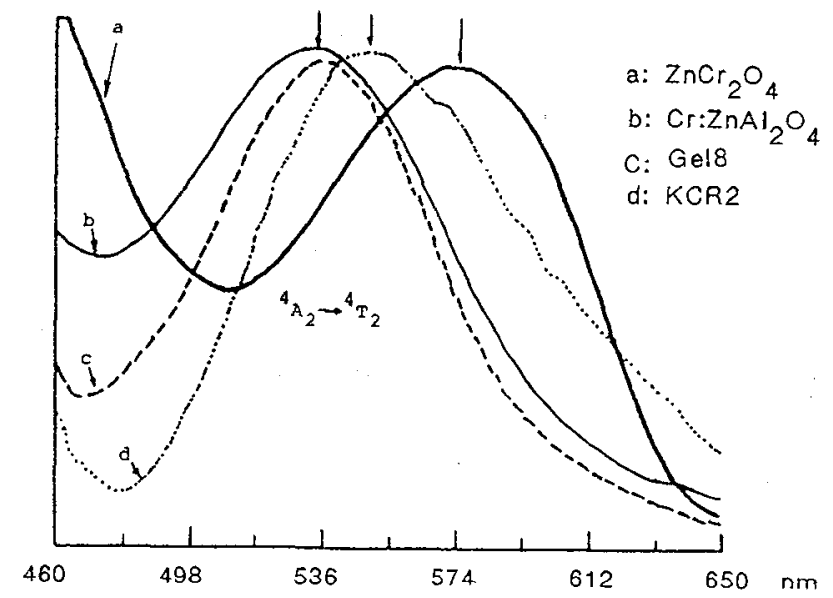

Fig. 2 Absorption spectra of Gel8 and KCR2 heated at $1000^{\circ} \mathrm{C}$ referenced with that of $\mathrm{Cr}^{3+}: \mathrm{ZnAl}_{2} \mathrm{O}_{4}$ and $\mathrm{ZnCr}_{2} \mathrm{O}_{4}$.

In summary. the crystallites in the studied system can be described with a general formula $\mathrm{Zn}\left(\mathrm{Al}(1-\mathrm{X}) \mathrm{CrX}_{2} \mathrm{O}_{4}\right.$ with $\mathrm{X}$ near to one at the beginning of nucleation and near to zero(for Gel8) or between one and zero(for KCR2) depending on the initial chromium concentrations. Chromium ion is the nucleating agent.

\section{Discussion and conclusion}

Optical probes are widely used for the study of structural evolutions. Organic dyes and fluorescent ions are among the main hinds $(9,10)$. We would like to discuss the validity of a probe and some general rules that should be followed concerning the choice of a structure probe.

There are two important aspects of an optically active structure probe: its validity and its sensitivity. The best probe would be the compromise of sensitivity/validity. 
There are two kinds of probes. i) Natural: probes are components of the systems studied. In this case, it has near $100 \%$ validity; ii) Purposeful: probes are intentionally added to the studied system. Structure evolutions are inferred from changes of optical properties of probes that directly related to their local environments. The best probes are those which bring the lowest perturbation to the system and are sensitive enough to detect minute local structure changes. The probe is also preferred to be located in appropriate sites. The worse probes are those which gives the highest perturbation resulting in structure changes or those insensitive to environment changes. In this case, the probes loose their credibility to the study.

In reality, people seek often probes with high optical sensitivity on sacrificing validity. In the current study, as a probe, $\mathrm{Cr}^{3+}$ gives important informations on nucleation and crystallization processes since not only it locates both in nuclei and final crystallites but also its optical and paramagnetical properties are very sentitive to local environment changes. If looked as a natural probe, $\mathrm{Cr}^{3+}$ has high environmental sensitivity and $100 \%$ validity. $\mathrm{Cr}^{3+}$ plays at the same time the role of a nucleating agent and a structure probe.

In conclusion, the sol-gel->glass->glass-ceramic transitions of the system $\mathrm{SiO}_{2}$ $\mathrm{ZnO}-\mathrm{Al}_{2} \mathrm{O}_{3}-\mathrm{Cr}_{2} \mathrm{O}_{3}$ are probed by $\mathrm{Cr}^{3+}$ through $\mathrm{ESR}$, optical absorption and laser spectroscopy as complementary techniques of X-ray diffraction, SAXS and TEM. The devitrification of the system is found to be initiated by the agreggation of $\mathrm{Cr}^{3+}$. The chemical composition of crystallites can be described by a general formula $\mathrm{Zn}\left(\mathrm{Al}_{(1-\mathrm{X})} \mathrm{CrX}\right)_{2} \mathrm{O}_{4}$ with X near to one in the nuclei and near to zero in the crystallisation stage.

\section{References}

[1] DURVille, F., Champagnon, B., Duval, E.,Boulon, G., J. Phys. Chem. Solids, $46(1985) 701$

[2] PONCON, V., NIE, W., BOUL.ON, G., Eur. J. Solid State Inorg. Chem., 26(1989)53

[3] BOULON, G., Mat. Chem. Phys.. 16(1987)301

[4] NIE, W., BOULON, G., MAII, C., ESNOUF, C., XU, R., ZARZYCKI, J., J. Non-Cryst. Solids, 121(1990)282

[5] NIE, W., BOULON, G., MAI. C., ESNOUf, C., XU, R., ZARZYCKI, J., Mat. Chem. Phys., $25(1990) 105-126$

[6] NIE, W.. BOUlon, G., MAI. C., ESNOUF, C., XU, R., ZARZYCKI, Chem. Mat., 4(1992)216-222

[7] NIE, W., MICHEL-CALENDINI, F.M., LINARES, C., BOULON, G., DAUL, C., J. I.umin., 46(1990) $177-190$

[8] NIE, W., BOULON, G., LU, Y., Eur. J. Solid State Inorg. Chem., 26(1989)551-574

[9] DUNN, B.D., KNOBBE, E.. McKIERNAN, J..POUXVIEL. J.C., ZINK, J.I., In Better Ceramics Through Chemistry III; BRINKER, C.J., CLARK, D.E., ULRICH, D.R., Eds.; MRS Symp. Proc. Vol. 121(1988) 331-342

[10] Achddou, J.C., Ph.D Thesis, ENSCM(Montpellier, France), 1991 